Marquette University

e-Publications@Marquette

Civil and Environmental Engineering Faculty

Civil and Environmental Engineering, Department

Research and Publications

$12-1-2017$

\title{
Higher Education on Buildings: Case Study in the North Dakota Region
}

Houjun Yang

North Dakota State University

Malini Srivastava

North Dakota State University

Yanmei Xie

North Dakota State University

Yong Bai

Marquette University, yong.bai@marquette.edu

Accepted version. Journal of Architectural Engineering, Vol. 23, No. 4 (December 2017). DOI. (C) 2017 American Society of Civil Engineers. Used with permission. 
Marquette University

e-Publications@Marquette

\section{Civil, Construction, and Environmental Engineering Faculty Research and Publications/College of Engineering}

This paper is NOT THE PUBLISHED VERSION; but the author's final, peer-reviewed manuscript. The published version may be accessed by following the link in the citation below.

Journal of Architectural Engineering, Vol. 23, No. 4 (December, 2017). DOI. This article is (C) American Society of Civil Engineers (ASCE) and permission has been granted for this version to appear in $\underline{\mathrm{e}-}$ Publications@Marquette. ASCE does not grant permission for this article to be further copied/distributed or hosted elsewhere without the express permission from ASCE.

\section{Higher Education on Buildings: Case Study in the North Dakota Region}

Huojun Yang

Department of Construction Management and Engineering, North Dakota State University, Fargo, ND Malini Srivastava

Department of Architecture and Landscape Architecture, North Dakota State University, Fargo, ND Yanmei Xie

Department of Construction Management and Engineering, North Dakota State University, Fargo, ND Yong Bai

Department of Civil Construction and Environment Engineering, Marquette University, Milwaukee, WI 


\section{Yao Yu}

Department of Construction Management and Engineering, North Dakota State University, Fargo, ND Bradley Bowen

School of Education, Integrative STEM Education, Virginia Tech, Blacksburg, VA

\section{Abstract}

Because of the growing demand for local skilled professionals to improve the health, energy efficiency, and sustainability of residential and commercial buildings in North Dakota, this case study reports the current situation of higher education relating to buildings in the state's vicinity, including Minnesota, Montana, North Dakota, and South Dakota. In this region, 116 programs relating to buildings were found in 41 postsecondary institutions, and both their majors and courses were then studied with frequency lists. The frequency information was analyzed over nine sets of curriculum areas at both graduate and undergraduate levels for the four states. After the current state of buildings in North Dakota was investigated, strategies were then proposed to rectify current issues regarding higher education on buildings, including but not limited to forming a comprehensive and interdisciplinary program on buildings (e.g., architectural engineering), providing more graduate programs, developing more courses in areas that lack adequate coursework, and increasing student enrollment. These strategies will greatly promote the health, energy efficiency, and sustainability for new and existing buildings in the four-state region of Minnesota, Montana, North Dakota, and South Dakota.

\section{Introduction}

Buildings are the biggest sector contributor to greenhouse gas emissions, and they consume $41 \%$ of primary energy, $72 \%$ of electricity, and $36 \%$ of natural gas in the United States. Although energy is important to both the environment and budgets, health and comfort are also important to building occupants. The World Health Organization (WHO) estimated that up to $30 \%$ of new or remodeled commercial buildings have unusually high rates of health and comfort complaints from occupants that may potentially be related to indoor air quality (IAQ) (EPA 2012). Today, 14\% of health care costs are incurred by conditions related to IAQ (Bloech 2014). In addition to IAQ, there are other physical and psychological factors of life indoors that affect the comfort of occupants in buildings, such as lighting, visual quality, acoustics, and thermal comfort.

Many of the factors regarding buildings' energy efficiency, health, and sustainability are interrelated and affected by one another. In many cases, the improvement of one factor in a building sacrifices the performance of another. For example, the current practice of a tighter and more energy-efficient construction, where the exchange of indoor and outdoor air is significantly reduced for energy savings, may have IAQ issues because unwanted contaminants will be trapped in the more compact environment (Bloech 2014). However, few studies have comprehensively covered how factors such as climate, building design, construction, building equipment, operation and maintenance, occupant behavior, IAQ, lighting, visual quality, acoustics, and thermal conditions impact building occupants' 
comfort and health as well as a building's performance. There is also a lack of investigation on how these factors interact with each other to impact a building's composite performance. In addition, with respect to a building's individual performance, further research is needed to find optimal solutions for discovering problematic situations affecting indoor quality, such as how to quickly detect and identify various indoor bioaerosols on site.

To rectify this situation, more professional experts are needed to effectively solve the current issues and to continuously provide innovations with respect to healthy, energy-efficient, and sustainable buildings. Higher education institutions are central to producing industry professionals across all topics related to buildings, such as building design, building mechanical systems, and indoor air quality. Many studies (Kruss et al. 2015; Lin 2004; Meulemeester and Rochat 1995) pointed out that higher education provides a positive and significant effect on economic development and technology innovations. Among academic disciplines related to buildings, architectural engineering ( $A E)$ is chosen because it is a comprehensive program dedicated entirely to buildings, compared with other programs that may only study buildings in one or part of one course (e.g., mechanical engineering). According to the recently published American Society for Engineering Education (ASEE) annual data report (Yoder 2015), over the course of 2014, AE saw an $8 \%$ decrease in bachelor's degrees and a $5 \%$ decrease in overall enrollment, resulting in 607 bachelor's degrees and a total enrollment of 3,237 students. There was also a $7 \%$ decrease in master's degrees and a $12 \%$ decrease in master's program enrollment, resulting in only 128 master's degrees and 256 master's program enrollment. Awarded doctoral degrees in AE remained small with a total of 15 for 2014, although the number jumped by $67 \%$ during the past year, and $A E$ doctoral enrollment remained unchanged with a total of 84 . Therefore, these numbers predict that overall $A E$ degree recipients in the United States will continue to decrease for the next several years. This declining number in AE professional production from higher education institutions will not meet the increasing technical need in the building sector, such as how to provide a healthier and more comfortable built environment with fewer resources and minor environmental impacts. However, there is a lack of research on the underlying causes of this mismatch, and additional research needs to be conducted to disclose more information about the current state of degrees, courses, and opportunities in higher education for building-related majors.

There is a geographical imbalance in the production of building-related professionals, with only 17 of 50 states in the United States having ABET-accredited AE programs (ABET 2017). Furthermore, there are no AE programs in the Great Plains region of Washington, Idaho, Montana, North Dakota, South Dakota, Minnesota, and lowa. The nearest to North Dakota are the AE programs at the University of Nebraska-Lincoln (UNL) in Lincoln, Nebraska and at the University of Wyoming in Laramie, Wyoming, over 400 miles away. Because of the shortage in AE degree recipients, the local building-related jobs will be filled by non-AE professionals or AE professionals from outside the region. Paradoxically, the Northern Great Plains in the United States, spanning the five states of Montana, Nebraska, North Dakota, South Dakota, and Wyoming, has the top building energy consumption per capita in the nation, ranging 160-220 MM Btu in 2014 according to the U.S. Energy Information Administration (EIA) (EIA 2017). Among the five states in the Northern Great Plains, North Dakota ranks first in the building energy consumption per capita. Moreover, North Dakota has already lagged far behind other states in the local region and in the nation with respect to building-related research and higher education. These issues are compounded by the building boom that has swept the state, with an estimated 
82,400 new residents that have moved to North Dakota between 2010 and 2015, creating more building-related jobs that need to be filled across different levels of education and skills.

This paper provides insight into the production of building-related professionals from higher education institutions based on a case study in the four-state region of North Dakota, South Dakota, Montana, and Minnesota. Although there are various perspectives about how to prepare future professionals (Ayer et al. 2016; Beaty et al. 2014; Berardi et al. 2014; Setareh et al. 2005, 2015; Waters and Moser 2000; Waters et al. 2012), this study focused on the core curricula of building-related programs. After investigating the status quo of buildings in North Dakota with respect to energy, health, and sustainability, the disciplines relating to buildings were dissected into a list of basic topics, and then the current curriculum for each topic was analyzed. All higher education institutions in the four states were studied after their current curriculum data were collected online from their websites. Finally, strategies including creating a more comprehensive program (e.g., AE) and offering more graduate courses relating to buildings were proposed so that more local professional experts are created in the field of buildings. This will help to rectify the current issues of buildings and continually support the healthy and sustainable buildings with high-energy efficiency across their lifetime.

\section{Status Quo of Buildings in North Dakota}

Most existing buildings in North Dakota do not meet the requirements of mainstream building energy codes [e.g., International Energy Conservation Code (IECC), International Building Code, and American National Standards Institute (ANSI)/American Society of Heating, Refrigerating and Air-Conditioning Engineers (ASHRAE) Standards 90.1 (2016) (Energy Standard for Buildings Except Low-Rise Residential Buildings) and 90.2 (2007) (Energy-Efficient Design of Low-Rise Residential Buildings)]. Furthermore, North Dakota has not adopted a statewide building energy code, although some of its local counties or jurisdictions have recently undertaken or are in the process of adopting building energy codes. The city of Fargo, North Dakota adopted the 2009 International Energy Conservation Code (International Code Council 2009) on June 14, 2010, but did not enforce any energy conservation code prior to 2010. The current state of buildings in North Dakota can be visualized through the following facts about the buildings at one of its universities. Most of the buildings on campus do not have energy monitoring of any kind, such as water, steam, or electrical meters. Without metering, it is challenging to evaluate energy systems. Many buildings have no automatic control systems, and even the pneumatic control systems currently installed only allow set points to be reset manually. Other issues include building air leakage, poor insulation, low-efficiency lighting, constant-speed motors, low-efficiency motors, and imbalanced HVAC airflow systems.

The energy consumption of buildings in North Dakota is significantly high due to both the lengthy cold winters and hot summers. In fact, not only does North Dakota have the highest building energy consumption per capita in its local region according to the U.S. EIA, but its residential building energy consumption per capita (105.1 MM Btu in 2014) and its commercial one (111.4 MM Btu in 2014) rank first and second in the nation, respectively (EIA 2017). In addition, North Dakota has the third lowest number of green buildings certified by Leadership in Energy and Environmental Design (LEED) in the nation. Furthermore, the long, cold, windy, and snowy winters make the residents in North Dakota 
spend more time in buildings than the average American; the U.S. EPA estimated that the average American spends approximately $90 \%$ of their time indoors. Thus, building energy consumption is increasingly affected by people's behavior, and their health will be more dependent on indoor environment quality. Also, buildings in North Dakota are subject to moisture issues due to flooding and snow, so more moisture-control techniques are required to avoid insulation degradation and the growth of bacteria and molds.

The issues mentioned earlier regarding buildings in North Dakota require solutions from skilled professionals whose knowledge is acquired through higher education, research, and practice. However, with respect to building-related higher education and research, North Dakota already lags far behind other states in the nation. This is evident by the lack of building-related resources and opportunities available in North Dakota. First, there is no comprehensive research center in North Dakota to focus on various aspects of buildings. Second, no specific program in the state funds the research on buildings' energy efficiency, health, and indoor environment. Third, although some specific topics relevant to buildings are studied in a few scattered departments of universities, there is no comprehensive program for addressing the complexity of the built environment in buildings. Last, very few case studies with respect to buildings have been conducted in North Dakota. For example, North Dakota was excluded in a recent study regarding concentrations of airborne culturable bacteria in 100 U.S. office buildings (Tsai and Macher 2005). More importantly, building-related jobs in North Dakota have increased due to the recent building boom that has swept the state, and an estimated 82,400 new residents moved to North Dakota between 2010 and 2015. This creates a need to produce more local building-related professionals in the four-state region of Minnesota, Montana, North Dakota, and South Dakota from higher education institutions to meet the labor force demand. Given the needs listed earlier, the authors conducted a case study, analyzing the current status and needs of buildingrelated programs in the region.

\section{Methods}

This study investigated all higher education institutions with postsecondary degrees in four states: Minnesota, Montana, North Dakota, and South Dakota. Then, current curricula or academic catalog data were collected online and further analyzed to find program majors relevant to buildings for all of these institutions. The criterion used to determine if a major relates to buildings is the course (i.e., a major is considered as relating to buildings only when it offers building-related courses). All different levels of majors are considered here: doctoral degree, master's degree, bachelor's degree, associate's degree, certificate, and diploma. The courses were further categorized into graduate-degree courses (offered for doctoral and master's degrees) and undergraduate courses (offered for bachelor's degree, associate's degree, certificate, and diploma) so that course levels can be further studied.

Only 41 higher education institutions in this region were found to have majors relevant to buildings. Table 1 lists all of the major programs related to buildings at different degree levels. For each degree level, the number in the "Frequency" column indicates the frequency of occurrence for each particular major program within the Program Name column, and the number in the "Number column is the degree level's total program number, whereas its percentage relative to the total number of all degree 
programs is listed within the "Percentage" column. There are a total of 116 different major programs with six different degree levels and 45 different program names. In this case study, all degree levels were included. Although professionals with associate's degrees, certificates, and diplomas may not have as significant of an effect on the design of buildings as those with at least a bachelor's degree, it was important to include them because they are part of the building sector community. This study contributes to a knowledge base that may impact the entire building ecosystem, including the entire building lifecycle and the professionals involved with each phase. Therefore, inclusion of all degree types was necessary to achieve the study's outcomes. This list of degree types includes majors that could also impact both residential and commercial construction, and therefore, the definition of buildings includes both construction types. As shown in Table 1 , the available majors have a variety of names that differ from the standard ASEE disciplines. The information also shows that the majority of program majors are associate's degrees, 54 degrees comprising $47 \%$ of the total, and there are very few Ph.D. degree programs, with eight degrees comprising $7 \%$ of the total.

Table 1. List of Majors Relating to Buildings in Higher Education Institutions in Minnesota, Montana, North Dakota, and South Dakota

\section{Degrees}

\section{Level Program subtotal}

Number

Doctoral 8

$3 \quad$ Mechanical engineering

Master's 19

4 Mechanical engineering; architecture

2 Construction management

1 Architecture-sustainable design;

construction engineering

Bachelor's 29

7 Construction management

$5 \quad$ Mechanical engineering

4 Architecture

2 Civil engineering technology

1 Architectural drafting and design;

construction engineering; interior design

\section{Percentage}

7

16

7

Civil engineering

Frequency Program name

\section{5}

Civil engineering

Program details

25

8

Civil engineering 


\section{Degrees}

Level

Program subtotal

Number

3

2

1

Building trades; construction

management; heating, ventilation and air conditioning

2 Architectural drafting and design; building construction technology; carpentry; construction technology; electrician; HVAC/R technology; sustainable energy technology

Architectural design and building construction; architectural drafting and estimating technology; architectural engineering technology; building construction management; building trades technology; construction; construction engineering technology; construction management technology; construction electrician; construction project management; drafting and design technology; electrical construction and maintenance; electrical, electronics and HVAC; general construction; heating and air conditioning engineering; heating and cooling technology; heating, $\mathrm{A} / \mathrm{C}$, ventilation and refrigeration maintenance technology/technician; HVAC installation and residential service; refrigeration and air conditioning technology; plumbing; residential plumbing/HVAC; sustainable construction technology; sustainable energy technician

Diploma/ 6

certificate

\section{Program details}

Frequency Program name
Percentage 


\section{Degrees}

Level
Program subtotal

Number

\section{Program details}

Frequency Program name

Percentage

technology; heating, ventilation and air

conditioning

Total 116

100

Before building-related courses were analyzed, the broad curriculum areas related to buildings were extracted, narrowed, and dissected into a list of basic topics by function. The whole curriculum area relevant to buildings was typically divided into nine separate topics: architecture and building design, building construction, building structures, building mechanical systems, building electrical and lighting systems, acoustics, fire protection, indoor environment, and sustainability. Then, each building-related course was categorized into one of the nine individual topics, and then into graduate- or undergraduate-level courses.

The 116 building-related programs offer a series of curricula with over 1,000 courses, and five steps were followed to reduce the number of studied courses and to highlight the case study focus. The first step was to only choose courses focused on the building application and to exclude their fundamental prerequisite courses. For example, calculus is commonly required by most universities, but it was not counted in this study because it is not dedicated to the building sector. In a similar manner, thermodynamics is a prerequisite of many courses in the energy discipline, but it was excluded from the study because it is not directly related to buildings.

The second step was to resolve differences in the use of course name terminology. In many cases, courses with different names include similar course topics. In some instances, it appears that the same course topics could be included in courses with two or more different names. For example, the curricula contained in courses labeled Architectural Drafting/Drawing, Architectural Drafting, Introduction to Drawing in Architecture, and Architectural Drawings and Methods were considered courses with significantly similar course topics. Therefore, in this example, the more common term, Architectural Drafting/Drawing, was retained to represent the course content, and the other lesscommon names were eliminated.

The third step was to identify courses covering more than one of the nine topics previously mentioned. For example, Soils and Foundation includes topics covered in both building construction and building structure. The courses were then listed in each area that they belong to (i.e., Soils and Foundation was listed in both the building construction and building structure areas).

The fourth step was to assign the same course topic to the different degree levels (e.g., bachelor's degree or master's degree). All courses were categorized into graduate and undergraduate levels, no matter what degrees the course is intended for. For example, HVAC courses are offered for master's 
degrees, bachelor's degrees, and associate's degree; therefore, they were considered as both graduate and undergraduate courses in this study.

Last, courses with the same name were considered as the same course in this study, although they may sometimes deal with slightly different learning topics among various institutions. When the course content could not be determined only by the course name, its syllabus was then studied in detail. The topics covered in the syllabus were used to determine the category of courses' curriculum areas.

The building-related courses were then compiled in Table $\underline{2}$ for undergraduate courses and Table $\underline{3}$ for graduate courses, categorized into the nine sets of the comprehensive curriculum area. For each curriculum area, the number in the "Frequency" column indicates the frequency of occurrence for each particular course within the "Course name" column (the number also showing how many programs contain the course or a similar course), and the number in the "Number" column is the curriculum area's total course number, whereas its percentage relative to the total number of all curriculum courses is listed within the "Percentage" column. The two tables tell us about the typical buildingrelated curriculum currently in place in the higher education institutions in the four-state region. The frequency number of course occurrence is particularly significant. In the next section of this paper, the frequency data are used to study three important questions: (1) What is the current body of knowledge (BOK) of building-related professionals from postsecondary institutions in the four-state region of Minnesota, Montana, North Dakota, and South Dakota? (2) What strategies can be proposed for curricula reform? (3) How much do these programs in the four states differ from each other?

Table 2. List of Building-Related Undergraduate Courses Appearing in Institutions in Minnesota, Montana, North Dakota, and South Dakota by Curriculum Area and Frequency of Occurrence

\section{Curriculum}

Area

Course subtotal Number

Architecture 39

and building

design

6

5

2

1
Architectural Design

Architectural Technology;

Building Systems

Building Information Modeling

Advanced Building Principles;

Building and Energy Codes;

Building Codes and Regulations;

Building Envelope Systems;

House Design and Code

Requirements; Intro to

\section{Undergraduate courses}

Frequency Course name

Percentage

13

13
Architectural
Drafting/Drawing 
Curriculum

Area

Course subtotal

Number

Architectural Theory; Residential

and Light Commercial Building

Codes; Residential Building Codes

Building 127

41

27

Frequency

Percentage

construction

22

20

8

7

6

4

2

1

Construction Management

Construction Estimating

Construction Safety

Soils and Foundation

Planning and Scheduling

Construction Scheduling; Project

Bidding and Estimating

Green Construction

Concrete and Sitework;

Construction Documents and

Specifications; Construction

Equipment; Construction

Management and Bid Estimation;

Framing Principles and Methods;

Specification and Contracts

Construction Contracts and

Introduction to Construction

Engineering; Construction Law

and Accounting (AW);

Construction Planning and

Management; Construction

Practicum; Construction

Surveying; Electrical and

Mechanical Construction;

Exterior Finish Theory and Shop;

Interior Finishing for Light

Commercial Construction;

Introduction to Light Commercial

Construction; Project Design in

Surveying; Site Layout and 
Curriculum

Area

Course subtotal

Number

Foundation Construction;

Sustainable Design and

Construction; Tools,

Construction, Carpentry;

Understanding Construction

Drawings

Building

62

20

structure

9

8

7

5

4

2

1

mechanical

systems

4

3

2

Steel Analysis and Design

Structures Concrete

Soils and Foundation

Prestressed Concrete Structures

Wood Analysis and Design

Concrete Design; Concrete and Sitework

Matrix Analysis of Structures;

Precast Concrete Structures; Soils and Concrete Technology

Undergraduate courses

Frequency Course name

Percentage

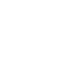




\section{Curriculum}

Area

1

Number

\section{Course subtotal}

Air Conditioning Design; Basic

Heating Systems; Cooling

Systems; Electrical Heating and

Air Conditioning; Heating and Air

Conditioning Controls; Heating

and Environmental Systems; Heat

Pump/Solar Heating Theory;

HVAC Systems Integration and

Controls; HVAC Troubleshooting

and Maintenance; Hydronic

Heating and Cooling Systems;

Hydronic Heating Systems; RE

Heating Equipment Theory;

Residential and Commercial

Refrigeration

\begin{tabular}{|c|c|c|c|c|}
\hline $\begin{array}{l}\text { Building } \\
\text { electrical and } \\
\text { lighting } \\
\text { systems }\end{array}$ & 14 & 4 & 5 & Electrical Design and Lighting \\
\hline 3 & $\begin{array}{l}\text { Lighting; Mechanical and } \\
\text { Electrical Systems }\end{array}$ & & & \\
\hline 2 & Lighting Equipment & & & \\
\hline 1 & Electrical Residential Design & & & \\
\hline $\begin{array}{l}\text { Indoor } \\
\text { environment }\end{array}$ & 6 & 2 & 3 & Environmental Systems \\
\hline 1 & $\begin{array}{l}\text { Designing for Indoor Comfort; } \\
\text { IAQ Indoor Air Quality; Indoor Air } \\
\text { Quality Solution }\end{array}$ & & & \\
\hline Sustainability & 17 & 5 & 3 & $\begin{array}{l}\text { Building Energy Efficiency; } \\
\text { Green Building Strategies; } \\
\text { Green Construction }\end{array}$ \\
\hline 2 & $\begin{array}{l}\text { Introduction of Sustainable } \\
\text { Building; LEED }\end{array}$ & & & \\
\hline 1 & $\begin{array}{l}\text { Introduction to Green Building } \\
\text { and LEED; Sustainable Building }\end{array}$ & & & \\
\hline
\end{tabular}

\section{Percentage}

\section{Frequency Course name \\ Undergraduate courses

Frequency




\section{Curriculum}

Area
Course subtotal

Number
Undergraduate courses

Frequency Course name

Systems and Regulations;

Sustainable Design and

Construction; Sustainability in the

Built Environment

Total

312

100

Table 3. List of Building-Related Graduate Courses Appearing in Institutions in Minnesota, Montana, North Dakota, and South Dakota by Curriculum Area and Frequency of Occurrence

\section{Curriculum}

Area

Architecture 24

and building

design

2

1

Number

\section{Course subtotal}

Advanced Architectural

Design/Studio; Architectural

Technology; Architectural Theory

Advanced Architectural Graphics;

Advanced Architectural Theory;

Advanced Building System

Integration; Advanced

Environmental Controls;

Architecture: Design, Form, Order, and Meaning; Building Methods in

Architecture; Building

Specification; Environmental

Technology; Introduction to

Computer Aided Architectural

Design; Theory of Architectural

Representation; 3D Computer

Architectural Modeling and

Design; Typology and

Architecture: Theories of Analysis

and Synthesis
Building $\quad 19$

construction

\section{Graduate courses}

\section{Frequency Course name}

\section{Percentage}

25.3

\section{3}

Architectural Design

Studio/Studies;

Architectural Practice
20

2

Advanced Construction

Management; Construction 


\section{Curriculum}

Area

1

Building

structure

4

3

2

1
Course subtotal Number

Advanced Applied Design and

Construction; Advanced Project

Planning and Control;

Construction Cost Estimating;

Construction Engineering and

Management; Construction

Organization Processes;

Construction Productivity;

Construction Support Operations;

Construction Theory; Residential

Construction and Costs;

Scheduling and Project Control;

Sustainable Design and

Construction
Management; Construction

Specifications and

Contracts; Construction

Technology and Equipment

$$
42
$$

Prestressed Concrete-Analysis and Design; Structural Stability

Advanced Structural Analysis and Design; Matrix Analysis of Structures

Advanced Steel Design; Ductile

Behavior of Steel Structures; Plate

Structures; Timber and Form

Design; Wood, Masonry,

Concrete, Steel Structures

Advanced Reinforced Concrete

Design; Applied Structural

Mechanics; Behavior of Concrete

Structures; Building Structural

Systems; Dynamics of Structures

and Foundations; Fracture of
44.

44.2

6

Structural Dynamics 


\section{Curriculum}

Area
Course subtotal Number

Materials and Structures;

Nonlinear Analysis of Structural

Systems; Plastic Design in

Structural Steel; Precast Concrete

Structures; Smart Structures;

Structural Reliability; Thin Shell

Structures

Building 4
mechanical
systems

Building 1

electrical and

lighting

systems

Indoor

0

environment

Sustainability 5
4.2

0

5.3

1

1
Air Conditioning and Refrigeration; Building Automation and Control Systems; Heating and Air Conditioning; HVAC Technology: Luminous and Thermal Design.

N/A

Energy and Indoor Environmental Quality in Sustainable Design; Material Performance in Sustainable Building; Site and Water in Sustainable Design; Sustainable Design and Construction; Sustainable Design Theory and Practice

Total

95

100

Frequency Data: Disclosing the BOK

Table $\underline{2}$ lists 312 undergraduate and Table $\underline{3}$ lists 95 graduate building-related courses currently offered by higher education institutions in Minnesota, Montana, North Dakota, and South Dakota. These courses are listed in the nine sets of curriculum areas relevant to buildings. There are several interesting points that emerge from Tables $\underline{2}$ and $\underline{3}$. First, the lists spell out what elements comprise today's building-related curriculum in the four-state region, disclosing the current BOK that is available 
to the local undergraduate and graduate students seeking education in the building sector. These courses define what is currently taught and form a baseline for assessment of the building-related curriculum of the present and future.

Second, the lists of 312 undergraduate and 95 graduate courses provide a means of determining the relative weight of various learning categories currently applied to building-related undergraduate and graduate degrees. As shown in Table 2 , the current undergraduate curriculum relevant to buildings is $41 \%$ construction, $20 \%$ structure, $15 \%$ mechanical systems, $13 \%$ architecture/design, $5 \%$ sustainability, $4 \%$ electrical and lighting, $2 \%$ indoor environment, and $0 \%$ fire protection and acoustics. Meanwhile, Table $\underline{3}$ reveals that the current building-related graduate curriculum is $44.2 \%$ structure; $25.3 \%$ architecture/design; $20 \%$ construction; $5.3 \%$ sustainability; $4.2 \%$ mechanical systems; $1 \%$ electrical and lighting; and $0 \%$ indoor environment, fire protection, and acoustics.

These statistics indicate an evident curriculum imbalance. There are many more undergraduate than graduate courses for each set of building-related courses in part because fewer graduate programs are offered than undergraduate ones, as indicated in Table 1 . In terms of curriculum areas, there are no courses specific to the areas of fire protection and acoustics for both undergraduate and graduate levels. Graduate courses also do not exist in the area of indoor environment, and $90 \%$ of graduate courses focus on the three areas (structure, architecture/design, and construction), with the highest weight in the area of structure at $44.2 \%$. Undergraduate courses, however, have a slightly more even distribution across the curriculum areas, with four areas (construction, structure, mechanical systems, and architecture/design) accounting for $88 \%$, with the highest weight (41\%) in construction. Courses in the areas of sustainability and electrical/lighting account for a very small proportion, below $5.3 \%$ for both graduate and undergraduate levels.

Third, an overall examination of the frequency information for both graduate and undergraduate courses in Tables $\underline{2}$ and $\underline{3}$ further explains the credential makeup of the professional community in the building sector in the four-state region. As shown in Table 4 , recent building-related graduates from the local higher education institutions have knowledge that averages from $36 \%$ construction, $26 \%$ structure, $15 \%$ architecture/design, $13 \%$ mechanical systems, 5\% sustainability, $4 \%$ electrical/lighting, $1 \%$ indoor environment, and $0 \%$ fire protection and acoustics. Construction and structure skills mainly make buildings durable (62\%); architecture/design, mechanical systems, and electrical/lighting skills make them functional (32\%); sustainability skills make them sustainable and energy-efficient (5\%); indoor environment and acoustics skills make them healthy and comfortable (1\%); and fire protection skills make them safe ( $0 \%)$. When this percentage proposition is combined with the fact that most courses are less advanced for undergraduate students than graduate students, particularly for associate's, certificate, and diploma degrees, it can be seen that the local professional community in the building sector has been and is continuing to make buildings durable and functional but not comfortable, energy-efficient, healthy, and sustainable. This is due to heavy course loads in construction, structure, and architecture/design, and very light course loads (particularly graduate course loads) in mechanical systems, sustainability, indoor environment, acoustics, and electrical/lighting. This credential composition of professionals relevant to buildings can account for the status quo of buildings in North Dakota as previously discussed: extremely low energy efficiency and less comfort, health, or sustainability. 
Table 4. Summary of Building-Related Courses Appearing in Institutions in Minnesota, Montana, North Dakota, and South Dakota by Curriculum Area and Frequency of Occurrence

\section{Curriculum area Frequency number Percentage}

$\begin{array}{lll}\text { Architecture/design } & 63 & 15 \\ \text { Construction } & 146 & 36 \\ \text { Structure } & 104 & 25.5 \\ \text { Mechanical } & 51 & 13 \\ \text { Electrical/lighting } & 15 & 4 \\ \text { Indoor Environment } 6 & 1.5 \\ \text { Sustainability } & 22 & 5 \\ \text { Total } & 407 & 100\end{array}$

Fourth, the course frequency information is a useful impetus for building-related curriculum reform. With the recent building boom in North Dakota and the increasingly advanced demands from building owners, occupants, and other parties, there is a need for buildings to be more energy-efficient and sustainable and to form a more healthy and comfortable environment. Paradoxically, these popular aspects are hardly mentioned among the courses most commonly found in the current building-related curriculum in the four-state region. Additional courses need to be developed so that the overall performance expectation of buildings in North Dakota can be met in terms of health, energy efficiency, and sustainability. Also, advanced graduate courses need to be developed in these areas to produce a qualified future workforce. In addition, the building-related course lists can be used as a basis to discuss how things might change with regard to interdisciplinary collaboration. The 407 courses relating to buildings are thinly scattered among the 116 total programs across different universities. This results in an average of 3.5 courses per program. Therefore, graduates from various institutions may not have a comprehensive BOK related to buildings allowing them to improve the overall performance of buildings in various respects, such as health, sustainability, and energy efficiency. Offering a comprehensive program specific to buildings, such as $A E$, may be a better alternative by providing a more comprehensive program that includes courses across the different curriculum areas relating to buildings.

Curriculum Comparison among Minnesota, Montana, North Dakota, and South Dakota

This study investigated all 41 institutions of higher education with respect to buildings in the previously mentioned four-state region. The breakdown of the number of institutions per state is as follows: 15 in Minnesota, 11 in Montana, seven in North Dakota, and eight in South Dakota. Tables $\underline{5}$ and $\underline{6}$ compare the frequency of undergraduate and graduate courses in various building-related curriculum areas for institutions in the four-state region. For each state, the first row is the curriculum area's course frequency, and the second row is its percentage in the state's total number of building-related courses. For undergraduate courses, the data in Table $\underline{5}$ indicate several common characteristics shared by all four states. The area of construction accounts for $38.5-43.5 \%$, a much greater average percentage 
than other curriculum areas. The area of indoor environment has the least weight, averaging $0-2.8 \%$, with the exception of $0 \%$ fire protection and acoustics. The data also demonstrate that there is an imbalance in weight for different curriculum areas within the states. Descriptive statistics show that Minnesota has a more even weight distribution among the curriculum areas, with a range of 2.8$38.5 \%$, than the other three states. In Montana, two spikes in the areas of construction and structure comprise the majority of courses at $75 \%$ of total courses taken, whereas other curriculum areas make up a much smaller percentage. North Dakota and South Dakota have a higher peak in the area of construction (43.5\%) than the other two states (38.5\%). In South Dakota, there are no courses in the areas of electrical/lighting and indoor environment. Further research is needed to determine the optimal percentage profile among these curriculum areas for an individual state.

Table 5. Comparison of Building-Related Undergraduate Course Sum in Institutions in Minnesota, Montana, North Dakota, and South Dakota by Curriculum Area and Frequency of Occurrence

Curriculum area

Minnesota [No. Montana [No. North Dakota [No. South Dakota [No. Total (\%)]

$\begin{array}{llllll}\text { Architecture/design } & 16 & (14.8) & 6 & (9.2) & 9 \\ \text { Construction } & 42 & (38.9) & 25 & (38.5) & 37 \\ \text { Structure } & 14 & (12.9) & 24 & (36.9) & 13 \\ \text { Mechanical } & 15 & (13.9) & 4 & (6.2) & 19 \\ \text { Electrical/lighting } & 10 & (9.3) & 2 & (3.1) & 2 \\ \text { Indoor } & 3 & (2.8) & 1 & (1.5) & 2 \\ \text { environment } & & & & & \\ \text { Sustainability } & 8 & (7.4) & 3 & (4.6) & 3 \\ \text { Total } & 108 & & 65 & & 85\end{array}$

$(\%)]$

(\%)]

$\begin{array}{clcl}(10.6) & 8 & (14.8) & 39 \\ (43.5) & 23 & (42.6) & 127 \\ (15.3) & 11 & (20.4) & 62 \\ (22.4) & 9 & (16.7) & 47 \\ (2.4) & 0 & (0) & 14 \\ (2.4) & 0 & (0) & 6 \\ & & & \\ (3.5) & 3 & (5.6) & 17 \\ & 54 & & 312\end{array}$

Table 6. Comparison of Building-Related Graduate Course Sum in Institutions among Minnesota, Montana, North Dakota, and South Dakota by Curriculum Area and Frequency of Occurrence

Curriculum area

\begin{tabular}{|c|c|c|c|c|c|c|c|c|c|}
\hline \multirow[b]{2}{*}{ Architecture/design } & \multicolumn{2}{|c|}{ Minnesota } & \multicolumn{2}{|c|}{ Montana } & \multicolumn{2}{|c|}{ North Dakota } & \multicolumn{2}{|c|}{ South Dakota } & \multirow{2}{*}{$\begin{array}{l}\text { Total } \\
24\end{array}$} \\
\hline & 9 & (31) & 7 & $(43.8)$ & 3 & $(10.1)$ & 5 & $(22.7)$ & \\
\hline Construction & 2 & (6.9) & 4 & $(25)$ & 8 & $(28.6)$ & 5 & $(22.7)$ & 19 \\
\hline Structure & 11 & (37.9) & 5 & (31.3) & 14 & (50) & 12 & $(54.5)$ & 42 \\
\hline Mechanical & 1 & $(3.4)$ & 0 & (0) & 3 & $(10.7)$ & 0 & (0) & 4 \\
\hline Electrical/lighting & 1 & $(3.4)$ & 0 & (0) & 0 & (0) & 0 & (0) & 1 \\
\hline Indoor environment & 0 & (0) & 0 & (0) & 0 & (0) & 0 & (0) & 0 \\
\hline
\end{tabular}




\section{Curriculum area}

Sustainability

Total
Minnesota

5

29
(17.2)

\section{Frequency}

North Dakota

(0)

28

\section{South Dakota Total}

(0)

5

95

With regard to graduate courses, the data in Table $\underline{6}$ show more $0 \%$ curriculum areas in graduate courses than undergraduate courses. No graduate courses are offered in the area of indoor environment for all four states, and only Minnesota offers courses related to building sustainability and electrical/lighting. Courses relevant to building mechanical systems are also lacking in Montana and South Dakota. Similar to Table $\underline{5}$, Table $\underline{6}$ shows that Minnesota has a more even weight distribution among these areas than the other three states. Unlike the undergraduate courses, the graduate courses in the area of construction represent a minor percentage share: $6.9 \%$ (the fourth largest percentage) in Minnesota, 25\% (the third largest) in Montana, 28.6\% (the second largest) in North Dakota, and $22.7 \%$ (the second largest) in South Dakota. The area of structure accounts for the largest percentage, up to $54.5 \%$ in South Dakota, 50\% in North Dakota, and 37.9\% in Minnesota, whereas that of architecture/design has the largest proportion (43.8\%) in Montana. In addition, although Minnesota provides many more undergraduate courses than the other three states, the frequency difference of graduate courses among the four states is relatively small, as shown in Table $\underline{6}$.

\section{Conclusions and Recommendations}

This case study analyzed the curriculum areas and courses related to buildings to draw conclusions on the current situation of higher education on the building sector in the four-state region of Minnesota, Montana, North Dakota, and South Dakota. This study intended to disclose the current state of higher learning in the area of buildings and to provide opinions on the direction building-related curriculum reform may take in the future.

The current curriculum area frequency lists define the programs and degrees that are currently provided in building-related postsecondary education. It is important to evaluate the plain statistics to assess the current and future opportunities of building-related professionals from higher education institutions. In the four-state region assessed in this study, it is critical to further predict the knowledge background and level of the whole professional community in the building sector, and then to justify the performance issues of existing buildings in the four-state region. It is also a useful measure for guiding reform or restructure of programs related to buildings.

The course frequency information further contributes to the existing research base by disclosing what is currently being taught with regard to buildings and that it may not necessarily be the ideal curriculum and balance of course offerings. It can, however, be considered an effective baseline for assessment and discussion about the building-related curriculum of the present and future in the fourstate region. 
This study found that the majority (approximately 77\%) of the degrees are offered to undergraduate students ( $25 \%$ for bachelor's degrees, $47 \%$ for associate's degrees, and $5 \%$ for diplomas/certificates), and doctorate and master's degrees only account for 7 and 16\%, respectively. The doctorate degrees relevant to buildings are only for mechanical engineering or civil engineering. Various programs for undergraduate students were found to have less-uniform names, especially for associate's degrees and diplomas/certificates, shown by the small frequency of occurrence (one or two) before a program name, as shown by the list of majors in Table $\underline{1}$.

The undergraduate and graduate course frequency data demonstrate a notable curriculum imbalance. First, many more undergraduate than graduate courses are offered for each of the nine sets of building-related curriculum areas. However, this is not surprising given there are many more undergraduate than graduate students and there are more credits hours required for undergraduate degrees. Second, for both undergraduate and graduate levels, no courses exist in the areas of fire protection and acoustics, and the courses in the areas of sustainability and electrical/lighting account for a very small portion of overall courses, below 5.5\%. Third, graduate courses also lack in the area of indoor environment, and $90 \%$ of them focus on three areas (structure, architecture/design, and construction), with the highest weight (44.2\%) in the area of structure. Last, undergraduate courses have a more even distribution across the curriculum areas, and four areas (construction, structure, mechanical systems, and architecture/design) account for $88 \%$, with the highest weight (41\%) in the area of construction.

The course frequency information describes the credentials of the professional community in the building sector in the four-state region, especially for the new professionals that have just recently graduated from one of the higher education institutions. On average, the professional skills are composed of $36 \%$ construction, $26 \%$ structure, $15 \%$ architecture/design, $13 \%$ mechanical systems, $5 \%$ sustainability, $4 \%$ electrical/lighting, $1 \%$ indoor environment, and $0 \%$ fire protection and acoustics. When these results are combined with the small frequency of advanced courses at the graduate level, it can be determined that, with regard to higher education, most of the professional efforts have been to make buildings durable and functional, but there is a lack of effort to make them comfortable, energy-efficient, healthy, and sustainable. Thus, this has led to the status quo of buildings in North Dakota and the surrounding states to have extremely low energy efficiency and lower levels of comfort, health, and sustainability.

The results of the curriculum comparisons among the four states show common features shared among the institutions and the specific course emphasis for each state. For undergraduate courses, all four states have construction as the highest percentage of course frequency among all nine curriculum areas, $38.5-43.5 \%$. There are no courses in fire protection and acoustics, and the second lowest is in the area of indoor environment. Minnesota has a more even frequency distribution among the curriculum areas than the other three states. Montana has the majority of courses in construction and structure, making up 75\% of all courses. North Dakota and South Dakota have a higher peak in construction (43.5\%) than the other two states (38.5\%). In addition to fire protection and acoustics, no courses exist in the areas of electrical/lighting and indoor environment in South Dakota. 
Graduate courses are lacking in even more curriculum areas. All four states have no courses not only in fire protection and acoustics, but also in the area of indoor environment. Only Minnesota offers courses relating to building sustainability and electrical/lighting. Courses relevant to building mechanical systems are also lacking in Montana and South Dakota. The area of structure accounts for the highest average percentage in South Dakota at 54.5\%, North Dakota at 50\%, and Minnesota at $37.9 \%$, which is a stark contrast to the undergraduate curriculum. Montana's largest proportion is in architecture/design at $43.8 \%$. Minnesota also tends to have a more even weight distribution among the curriculum areas than the other three states.

This case study analyzed the major programs and curricula related to buildings in the four-state region of Minnesota, Montana, North Dakota, and South Dakota. The results allow for a further understanding of the current knowledge base and promote discussion to propose curriculum reform and program restructure in this region. It is evident that more graduate courses are needed to cover a wider variety of the curriculum areas. More courses are needed in the areas of indoor environment, sustainability, acoustics, mechanical systems, and fire protection, at both the undergraduate and graduate levels, to produce local professionals with a more comprehensive skill set to address the current issues of existing and new buildings in the region. Designing, constructing, and maintaining buildings to be healthier, more comfortable, energy-efficient, safe, and sustainable is a significant future concern for the region. A comprehensive program related to buildings, such as $A E$, may be vital in producing professionals with more comprehensive and integrated skills regarding building systems in the four-state region. Additional research similar to this study and that of other topical analyses of curriculum (Jarosz and Busch-Vishniac, 2006) is necessary to further identify the detailed BOK related to building-related curricula, an ideal course composition and sequence, and possibilities for developing an integrative building curriculum (Froyd and Ohland 2005). Further research will be needed to develop strategies on how to increase the student enrollment in bachelor's and/or higher degree paths in building-related programs, such as by engaging high school students in building-related higher education, or moving students in associate's degrees (accounting for nearly half of degrees offered in building-related programs) to bachelor's or higher degrees.

\section{References}

1 ABET. (2017). "ABET accredited program search."

http://main.abet.org/aps/Accreditedprogramsearch.aspx $\rangle$ (Jan. 14, 2017).

2 ASHRAE. (2007). "Energy efficient design of low-rise residential buildings." ANSI/ASHRAE/IES

Standard 90.2-2007, American Society of Heating, Refrigerating and Air Conditioning Engineers, Atlanta, GA.

3 ASHRAE. (2016). "Energy standard for buildings except low-rise residential buildings." ANSI/ASHRAE/IES Standard 90.1-2016, American Society of Heating, Refrigerating and Air Conditioning Engineers, Atlanta, GA.

4 Ayer, S. K., Messner, J. I., and Anumba, C. J. (2016). "Augmented reality gaming in sustainable design education.” J. Archit. Eng., 10.1061/(ASCE)AE.1943-5568.0000195, 04015012. 
5 Beaty, C. S., Waters, C. E., Dziuvenis, G. R., and Feldman, T. M. (2014). “Use of professional industry interaction to enhance engineering education." J. Archit. Eng., 10.1061/(ASCE)AE.1943$5568.0000148,05014001$.

6 Berardi, U., Pietroforte, R., and El-Korchi, T. (2014). "Acoustics and lighting education in architectural engineering: Experience of WPI." J. Archit. Eng., 10.1061/(ASCE)AE.1943-5568.0000142, 05013003.

7 Bloech, H. (2014). "Pioneering indoor air quality certification for buildings." http://newscience.ul.com/articles/pioneering-indoor-air-quality-certification-for-buildings $\rangle$ (Sep. 20, 2017).

8 EIA (U.S. Energy Information Administration). (2017). "State Energy Data System (SEDS): 1960-2015 (complete)." 〈http://www.eia.gov/state/seds/seds-data-complete.cfm?sid=US〉 (Jan. 14, 2017).

9 EPA. (2012). "The inside story: A guide to indoor air quality." http://www.epa.gov/iaq/pubs/insidestory.html) (Sep. 19, 2014).

10 Froyd, J., and Ohland, M. (2005). “Integrated engineering curricula." J. Eng. Educ., 94(11), 147-164.

11 International Code Council. (2009). 2009 International energy conservation code, International Code Council, Inc., Washington, DC.

12 Jarosz, J. P., and Busch-Vishniac, I. J. (2006). "A topical analysis of mechanical engineering curricula."

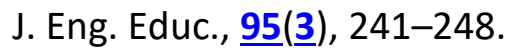

13 Kruss, G., McGrath, S., Petersen, I., and Gastrow, M. (2015). "Higher education and economic development: The importance of building technological capabilities." Int. J. Educ. Dev., 43, 2231.

14 Lin, T. (2004). "The role of higher education in economic development: An empirical study of Taiwan case." J. Asian Econ., 15(2), 355-371.

15 Meulemeester, J. D., and Rochat, D. (1995). “A causality analysis of the link between higher education and economic development." Econ. Educ. Rev., 14(4)), 351-361.

16 Setareh, M., Bowman, D. A., Kalita, A., Gracey, M., and Lucas, J. (2005). "Application of a virtual environment system in building sciences education." J. Archit. Eng., 10.1061/(ASCE)10760431(2005)11:4(165), 165-172.

17 Setareh, M., Jones, B., Ma, L., Bacim, F., and Polys, N. (2015). "Application and evaluation of doublelayer grid spatial structures for the engineering education of architects." J. Archit. Eng., 10.1061/(ASCE)AE.1943-5568.0000179, 04015005.

18 Tsai, F. C., and Macher, J. M. (2005). "Concentrations of airborne culturable bacteria in 100 large US office buildings from the BASE study." Indoor Air, 15 $\underline{\text { (s9) }}$ ), 71-81.

19 Waters, C. E., Alvine, S., and Eble-Hankins, M. (2012). "Industry-experienced graduate student program: Innovative collaboration in architectural engineering at the University of Nebraska, Lincoln." J. Archit. Eng., 10.1061/(ASCE)AE.1943-5568.0000046, 61-63.

20 Waters, C. E., and Moser, S. (2000). "Combined BS and MS degree program in architectural engineering.” J. Archit. Eng., 10.1061/(ASCE)1076-0431(2000)6:3(95), 95-97. 
21 Yoder, B. (2015). "Engineering by the numbers." American Society for Engineering Education (ASEE) Annual Data Rep. 〈https://www.asee.org/papers-and-publications/publications/collegeprofiles/15EngineeringbytheNumbersPart1.pdf $\rangle$ (Sep. 20, 2017). 